\title{
Santrinization and Egalitarian Spirit: A Case Study of Santri Village Community in Jombang, Indonesia
}

\author{
Tadjoer Ridjal $^{1} \quad$ Suharnan $^{2}$ Effy Indriati ${ }^{3} \quad$ Suko Susilo $^{4}$ \\ 1.Departement of Sociology: University of Darul 'Ulum Jombang \\ 2.Departement of Psychology: University of Darul 'Ulum Jombang \\ 3.Departement of Agriculture: University of Darul 'Ulum Jombang \\ 4.Departement of Da'wah: Islamic Institute of Tribhakti Kediri
}

\begin{abstract}
This research focus is tradition changes to illustrate the developments movement the meaning of society cultural identity. This research uses qualitative approach. The unit analysis is individual. The experiences of research subject, both in internal and existential condition, become main concern. The findings show that religious traditions of tahlilan in village communities are experiencing Santrinization in association with sociality typology of their lifestyle. Religious tradition generally is based on a loose grid, but emphasized on strong group bond, or a manifestation of egalitarianism principle.
\end{abstract}

Keywords: Santrinization, tahlilan, cultural identity, egalitarian.

DOI: $10.7176 / \mathrm{HRL} / 48-04$

\section{A. Introduction}

This research focus is traditions changes or the rhythm of daily life of community members in village and social life characteristics which originally seen as bound by a single tradition in imagined frame (this term was borrowed from Benedict Anderson (1983; 2006), which originally imagined communities), it shows the gap with its virtual frame (this term is borrowed from Timothy W. Luke $(1995,2003)$, which introduced the term virtual communities as a reaction to imagined communities of Anderson (1983)). Virtual frame is further alleged become frame of community members in social life of new imagined. This situation illustrates the meaning development movement of their cultural identity.

Beside related to cultural identity, live atmosphere scenery they face are associated with an effort to search alternatives that may give a promising value. These conditions are described by Bauman (1995) with the term of searching for a center that holds. Researchers suspect that community has been change the value orientation that manifested by behavior changes and individuals actions. This research is guided by view that villagers are considered to have their own sociality, because the sociality types as described by Gordon (2003), also occurred in village. It is supported by altruism spirit as the main characteristic of human society sociality. Some traditions as religious rituals always are coupled with "eat together" that also based on this altruism attitude.

\section{B. Framework and Methodology}

Habitat or the social environment where individuals become members of society everyday life can influence their habits, i.e. the life rhythm or behavior patterns and individuals actions as society members in their daily lives. The relationship between habitat and habit creation is not directly, but through the mediation of cognition within the individuals. The habit creation relies heavily on their thoughts on habitat, which is kind of habitus (Bourdieu, 1994) or certain dominant value orientation in daily lives, and vice versa. The relation between habitat, habits and habitus shows the mutual influence. It is similar to a mutual relationship between "personalbehavior-environment" in term of inter-locking determinants (Bandura, 1977; Reed, MS et al, 2010), or between cultural bias and social relations which relate respectively to edify one another, compatibility conditions (Thompson, et al , 1990). The changes of one component will be affected by the changes of other components.

The relationship between habitat and habit creation rely heavily on cognition mediation system. Habit is a product of human thought to the habitat, or individuals define the information provided in habitat, which research is called, to borrow a phrase Bourdieu (1994), as habitus. How individuals think about the situation and condition of its habitat based on value orientation will determine how to shape the reaction on habitat, or the habit in habitat. Therefore, change level comes from the dominance of a certain value orientations developed in individuals thinking. The dominant value orientation change within individuals will affect their way to interpret the information provided in these habitats, these changes in turn lead to changes in habits or rhythms of individuals daily life as members of society, and vice versa.

This research was conducted at a Sumberarum Village, Jombang District, East Java, Indonesia. This research uses the qualitative approach. The analysis unit is individual. The subject experience, both internal and existential condition, becomes a major concern. The research subjects are individuals who come from wong njero, wong njaba, and wong mambu-mambu.

The data collection process is relied on triangulation strategy, using engagement observation techniques, 
unstructured interviews, and document. Data is analyzed by flow chart from Miles and Huberman (1994). Therefore, process of data collection and data analysis is done simultaneously.

\section{Data Exposure and Discussion}

Same as other villages, Most Sumberarum communities work in agricultural sector. Farmer society lifestyle is more prominent at this village. The characteristic of stratified agrarian - as told by Sanderson (1995) - also appear in this village.

In case of agricultural land tenure, most of them are farm labor who do not have field. Using the term from Norldholt (1987), most of them is included as magersaren type, while Breman (1983) uses the "ride" term. The most job type for them is agricultural labor. In addition, other works are carpenter and stone, rickshaw pullers, factory workers, and ngemblek (take teak wood at forest), as well as some household work.

Although not identical, society structure developed in Sumberarum village is not seemed much different from the structure of Javanese village in general. As stated by Geertz (1981),structure of Javanese village communities generally under the influence of Islam and colonial. Based on system of cultural values, Geertz (1960) classifies the Java community to santri, priyayi, and abangan. The classification from Legge (in Muchtarom, 1988) raises the danger of messing up the different categories, because in fact there is santri-priyayi or abangan-priyayi. Therefore, McVey (1970) asserts that Java community is actually divided into two parts of culture, namely santri class and abangan class.

Sumberarum society is divided into three sub-identity, i.e.wong njero, wong njaba and wong mambumambu. Wong njero is an identity symbol of family members of village cleric's family. Wong njaba is a symbol to depict the identity of communities members that politically and socially are located in lower strata and most of village administration in general are symbolized as wong mambu-mambu. Based on kinship, members of wong mambu-mambu consider himself still had an alliance with wong njero. While those who come from the wong njaba consider himself unrelated directly with two other class, especially with wong njero.

According to legends within community, the founder of village (read: pembabat alas) is Mbah Kiai Isman. He is a descendant of Alif Prince, a Majapahit scholar buried at Betek, Mojoagung. The grave of Alif Prince is visited by many pilgrims, especially every legiFriday night. After the Isman death, village religion leadership was continued by his son Hasani. At his time began to use wong njero, wong njaba, and wong mambu-mambu terms.

Wong njero is an identity symbol of that attributed to descendants of Hasani family members who have never married with wong njaba. This class is believed to have levels higher in terms of religious knowledge mastery and formal education than the other class. In addition, wong njero is also symbolized as a social control model for religious and moral life. Therefore, every religious social activity such as lectures and communal party (slametan) always led by representatives of these class, or at least to lead pray. In addition, those who come from wong njero also get special treatment in daily communication with other community members, especially with wong njaba. This can be observed on names calling that always given addition subasita words, respect calling. With regard to such calls, this family groups generally regard their religious behavior is a reflection of the "village santri" or kedhung agama (a symbol of religious village). Although not exactly the same, it is resemblance to opinion of Elias (1988) regarding the process of civilization originating from the code of conduct of palace life in Europe.

Wong njero is symbolized as a model for social life. It may have similarities with Mennel analysis toward theory of civilization from Elias. Mennel (in Waters, 1994) says that people who had noble transformation process is a society that has specialists to became modeling and controlling of social behavior. However, they sometimes act adversely. This was happened in Sumberarum Village around 1970, when a member wong njero that punishing a child from wong njaba who steal cassava with ngangkrang punishment, i.e. punishment with big red ants bites. According to executioners of wong njero, such actions were done to educate children to hold on to appropriate moral, namely village santri or religion kedhung. Such thing seems consistent with statement of Evers (1988) that civilization process produces dialectically savagery. In other words, barbaric action is committed by people who consider themselves as civilized.

Wong mambu-mambu is symbols of group identity who consider themselves still have a kinship with wong njero. However, they also consider to have kinship with wong njaba. According to them, an alliance with other two groups is supposedly originated from a marriage between a son of Isman with wong njaba. However, at that time the wong njaba calling still not used. At that time, wong njaba still known as wong loran, meaning the people who live at northern end of village. In that time, people who lived in northern end of village are mostly migrants who generally work as farm labor.

Amalgamation is able to bridge the cultural differences the two families. Therefore, individuals who are believed to have originated from the "wong mambu-mambu" in the end be treated differently by members of the "wong njero", from their treatment of "wong njaba". Diba activities, for example, the management authority given to adolescents who are believed to have descended from the "wong mambu-mambu" Therefore, residents 
of the "wong njaba" to give a reference to individual members of the "wong mambu-mambu" as "bala njero", as meaning that there is still a relationship with "wong njero".

Most members of wong njaba does not relate directly with two other classes, especially with wong njero. Most of them consist of poor families who "ride" or magersaren. Generally, the religious knowledge and formal education are relatively lower than the other two classes. They are seen as not part of village santri, so they are also named as wong kedhusan, which means people who have many sin, or act like wedhus (goat). In fact, most of Sumberarum villagers believe that some children from wong njaba in the past born from ramban. The ramban term shows goats behavior to eat grass or leaves in any place. Like the goats behavior, some of their children are born without a father. Even among wong njaba also occurred taboo incestuous sexual relationship between brother and sister to give birth to two children.

They are often seen by wong njeroas people who easily commit adultery, violation of religion prohibitions. They are community members who dominate the number of people physically involved in mutual cooperation activities. However, lately they are often mbanggel, or refuse the order. Lichbach (1994) says that such actions include one type of peasant resistance. As a result, their attitude towards the activities of mutual cooperation for village benefit is now done with mreman purakan, which worked together with daily wage.

In case of agricultural land tenure, wong njero control about $45 \%$ of agricultural land at village, economically more advantaged than other class. Wong mambu-mambu control almost $35 \%$, and rest is controlled by wong njaba. In fact, most family members of wong njaba are classified as "rider" or full magersaren. This third class seemed only get land since the Isman time, and wong djaba - until the time of research-never buy land from other two classes.

As mentioned in previous section the symbol of cultural identity was apparently stems from Sumberarum village that known as santri village or religion kedhung. Before that time, Sumberarum residents only differentiated into wong loran and wong kidulan. Wong Loran is people who live in north village area, and wong kidulan are those who reside in southern village. Santrinization at Sumberarum determines the culture dominant value orientation in everyday life. Those who deviated from the dominant culture is seen not part of Sumberarum citizens, so it is called wong njaba. In fact, wong njaba is derogated as kedhusan.

In everyday life, the difference is manifested through a designation to shows where class the individuals come. In the past, most striking difference between wong njero and wong njaba is a religious rituals tradition to honor the spirits of those who died. Wong njero uses memorial ceremony through tahlilan tradition (chanting prayers in Islam), while wong njaba uses nyepaki tradition (providing food and smoke incense). Through Santrinization, nyepaki tradition at Sumberarum village is no longer done. All citizens have received tahlilan tradition. In fact, some of wong njaba have been trusted by citizens as a tahlilan leader.

Mr. Wak(local term: Pak Wak) is wong njaba who perform socio-religious rituals that previously only done by wong njero. Mr. Wak is tahlilan leader for religious social activities among wong njaba. Mr. Wak was appointed solely by wong njaba through mechanisms to their members who are considered to have the following criteria: can read and teach the Quran in his class, and often becomes a priest prayer. Mr. Wak who frequently performs these tasks among them is Sailan (mason), Sujai (peasant) and Mudasir (tailor). With Mr. Wak existence, the religious event at small-scale no longer have to wait for or invite representatives of wong njero.

Mr. Wak seems to perform tasks as performed by priest of wong djero. In the past, breaking the wewaler (sacred rules) is classified as as nyulayani adat (deviation from tradition). Along with these changes, identity symbols that appear before and after Sumberarum become religion kedhung, no longer concerned. Society seems construct a new identity to binds the diversity of traditional particularistic identity. They call this new identity as padha tampare. The new identity was emerge along with passage of Sumberarum Santrinization.

The results showed that identity symbol as santri village or religious kedhunghave changed their previous social formations that are based on historical considerations, namely wong kidulan (the members of village founder) and wong Loran (immigrants). Santrinization of community members are distinguished on basis of cultural value orientation, so the historical dichotomy is replaced by a cultural dichotomy, namely: the class of gendera ijo (santri) and gendero abang (abangan-non santri). These dichotomy is consistent with kiratanama of their area, Jombang. However, this classification still affected by conception inheritance of past, namely the conception of concentric power class (Rahman, 1995), as well as conception changes of Javaneseness (Lombart, 2005). Therefore, these patterns are based on concept of mandala, creating order thinking related the social formation that determined by its proximity to center.

Ridjal (2004) stated that change movement in Javaneseness conception is: from gak Jawa or durung (such as childhood), move towards rada Jawa (such as youth), to become wis Jawa (adulthood). Based on above conception, Ridjal (2004) adds that individuals as society members in turn is divided into three class, based on assessment of "santri levels" with " Java Psychology " pattern or "Javaneseness" conception, i.e. citizens:

1) Durung santri, which means do not manifest the symbol identity of santri,

2) Rada santri, which means to manifest symbol of identity of rather santri,

3) Wis santri, which means have manifested a identity symbol of santri. 
The pattern to assess the cultural identity of society creates an orderly thinking based on mandala concept. This conception is manifested to structure the identity of locality based on proximity to central symbol of dominant culture.

Cultural division that follows the mandala spectrum is reflected in arrangement of residential location as society members. Along with Santrinization, center circle in society view is Masjid. Mandala Masjid is a dominant symbols of value orientation that serves as an appraiser behavior and individuals actions as members, or santri levels. The farther from the center of dominant symbol value orientation, the santri value seen increasingly dims. Therefore, subsequent development of individuals as society members is divided into: wong njero, wong mambu-mambu, and wong njaba. Wong njero controlthe dominant value, and wong njaba have far relationship from the center of dominant symbol value orientation and seen as wong kedhusan.

Every social order is a manifestation of society's culture dominant value orientation (Thompson et.al, 1990), which became a written script (Biddle and Thomas, 1966), in minds of individuals symbolic. Wong njaba or wong kedhusan is a picture of individuals who perform inconsistent actions with dominant value orientation of santri village in according to social order or religion kedhung. In terms of religious traditions, wong njaba is identical to abangan (Geertz, 1960). The symbolic nature of mind leads their actions to interact among individuals between the class. It provides an action instruction to individuals in their daily lives, or imagined injunctions (Goulding and Goulding, 1979). Goodenough (in Casson, 1981) argues that culture is the cognitive system that ideal in individuals thought as society members. The thought pattern is the mediator relationship between social facts. Doob (1967) term it as mediating response, Keasing (1981) called it as a cultural performance, Wallace (1981) in concept of mediating schemata, and Ellis (1982) call this as belief system, and Bourdeau (1994) call it as habitus.

The daily life of individuals as society members took place in ebb and flow between the consolidation of culture in the tradition, and renewal of culture through change and reform. Furthermore, community has developed the identities construction to achieve development of a tradition to integrate individuals as the members. The emergence of a tradition to follows the people development process always involves the dialectic between continuity and discontinuity, competition between consolidation and transformation, succession between order and change. All of them create symphony to break down and to build (Kleden, 1984). Along with Santrinization, the classification of individual's culture as society members is based on process.

Although the social formation is a manifestation of differences in background of cultural value orientation, it does not mean to limit the space for social interaction for each members. Everyday social interactions allow dialogue between the value orientation. Identity as a self-intersubjective construction (Oyserman and Packer, 1996 and Edberg, 2015), allows the occurrence of a social contact, social negotiation, meanings and values (Markus and Kitayama, 1994).Markus and Kitayama views are also stated by Goddard and Ye (2016), and Parrott, WG (2001). In turn, society will be based on a tradition that can accommodate the orientation value, because by relying on a tradition the cultural value orientation can be maintained.

Social value development within social formations still inherits concentric conception to make hierarchical nature. Individuals from wong njero affect to determine the validity of a vertical orientation, through matching, namely its association with "symbols of power" (Anderson, 1991) in past. Legitimating effort of power symbol relies on creation of local history, which generally is shaped by "oral history" (Vansina, 1973; Allen, RL, 2017). This history type of work for stability and order value (Williams, 1977).With an emphasis on vertical orientation, pattern of social relationships was influenced by such patterns. This is reflected in oral discourse in dialogue between the class. Linguistic evidence shows positional relationship, especially oral discourse in dialogue between the parties in Sumberarum village. It confirms that language is a symbolic presentation of a culture (Mahadi and Jafari, 2012).

In thought conception of concentric class, movement may only change from the center to periphery or from the periphery to center, and can only be carried out by individuals who have central power and guaranteeing the relationship between center and periphery (Lombart, 2005). The mediators are not only among the wong njero or wong mambu-mambu, but also from among wong njaba, known as hadam and badal. As a result, the social fabric creates consequences that no longer follow an orderly thought legacy from past, namely the emergence of a new term of padha tampare. Santrinization to transmits Islamic elements seem to offer the egalitarian spirit to gradually change the patterns in a hierarchical social order of society. This spirit gradually delivers value orientation or thinking patterns of individuals to build a model of society to put each members in a parallel position. Or, thinking to see everyone has the same opportunities, and should be treated equally. The difference cannot be eliminated perfectly, maqame dhewe-dhewe (acknowledging the individual differences, so it create mutual respect), but in social life is displayed is the same treatment.

The changing pattern of social relations among wong njero reemphasize the dominant symbol value orientation in early days of Santrinization, namely ngramekna masjid (mosque prosperity), to maintain spirit of togetherness. Mosque, institutionally become the center of mandala, is characterized by hierarchical structure of society, but substantially masjid is an open place, regardless of individual's social position. Masjid not just run a 
ritual function as a place to pray, but also carry out social functions, meetings between internal individuals. Social distance (Allport, 1958; Bogardus, 1959) between the structure to be closed, creating the proximity (Coon, 1985). This situation in according to Newcomb (1960) support the creation of interpersonal relationship based on positive interpersonal attraction. In turn, social relations between individuals become closer regardless the social position. In this way, individuals as of society member gradually develop a conception of thinking about the togetherness spirit value. This confirms that cultural community was related to identity issue (van Meiji, 2008).

Identity that accommodates the value diversity will rely on tradition survival as a foothold to preserve tradition, namely religion ritual tradition. This tradition has become a habit as a reflection of people culture (van Meiji, 2008). Following the views of Kleden (1984), relying on diversity integration of individual cultural traditions can be awakened and a new identity in relation to that tradition can be maintained. Maintenance of this tradition is an effort to build and maintain santri identity. Various village religious tradition - especially tahlilan, is applied to sustain identity, namely socio-religious ritual traditions to support Santrinization.

At first, the changes in wong njaba tradition also means to touch the construction of identities, because it provides new information that requires them to take a stand. In turn, this situation threatens the reliability of cognitive structure. Social order no longer provides security guarantee, and cognitive structure in dissonance condition. In such situations, individuals as society members try to balance the cognitive structure. Effort to balance the cognitive structure has undergone a dissonance condition to determine the form of their social action in face of social order change. Therefore, the form of counter hegemony actions will depend on selective incentives ( Lichbanh, 1994), which is viewed favorably.

Efforts to balance the cognitive structures are not always manifested in form of resistance, because only the cognitive structure is distorted. Individuals who experience this state will take action if there is ambiguous. They receive a portion, in sense of not leaving the previous value, the blend was built, new values, new social order is dominated by new traditional values built, or similar to cultural syncretism (Geertz, 1993). Ketaksaan or ambiguous attitude is characteristic of society members based on value orientation development of society who has such conditions. Manifestations of other balance cognitive structure is done through adaptive measures, more appropriate as a form of "defeat reaction" (Onghokham, 1984), in process of hegemony. The creation of new myths is an attempt to legitimize that (Kartodirdjo, 1984). They accept fully the new values to abandon their previous values.

In Santrinization, tahlilan ritual tradition is associated with honor funerals, because it is a reflection of altruistic basic of human sociality. The funeral ceremony was performed in relatively the same regardless of social position: washed, shrouded, prayed, departure ceremony, and burial. In evening, reading Koran or tahlilan are held for seven days. There is no different treatment based on social position. It is realization of equality social life, in sense that everyone is entitled to equal treatment. Therefore, ritual tradition implementation is guided by a sense of emovemental attachment as well as supra-emovemental between individuals as society members. With tahlilan, people were taken towards the idea that there is no perfection, only to improve the weakness, through help to send prayers; like nonutopianism (Ellis, 1987). Social issues are resolved through principles of reducing the suffer of both sides, negative utilitarianism (Gordon, 2003). Tahlilan is always accompanied by puluran (food), and distributed in according with rhythm of sak-takir takir dhing, meaning that every person get equal share.

Emphasizing individuals as controller tradition, rather than a position in social structure, then Santrinization develop badal status (representative of Kyai). This patter causes fragmentation of structure, which in turn stimulates status anxiety. The relationship between structure is based on "emotion management" feeling (Wouters, 1992), so the superiority and inferiority feeling is avoided. The achievement is concerned, the transformation follow the ascriptive patter. Opportunity become controllers, tradition begins to open, regardless the origin of social position, namely with advent of Mr Wak. The badal always come from the wong njaba. It is an attempt to "share power" to involve all elements of society. Therefore, religious tradition was based on a loose grid, but stressed the strong group bond, or a manifestation of egalitarianism principle (Thompson et al, 1990).

\section{Conclusion}

Along with Sumberarum Santrinization, culture of ngramekna masjid was developed. Spectrum "mandala" is centered on masjid as determinant of santri levels of the individual members. The farther away from the mosque, the santri level is seen increasingly dims. Designations in associated with residential location of individual society create: wong njero, wong mambu-mambu. Even wong njaba is said as wong kedhusan. Construction of individual identity is related to individual house location background, regarding to values and traditions.

Sumberarum Santrinization relies on ritual traditions. Tahlilan tradition emphasizes the social contract and civic bond become precedence. Resources distribution in ritual tradition follows the rhythm of sak-takir takir dhing: everyone is treated equally regardless the background and social position. Related to above description, Santrinization give "egalitarian spirit" and gradually removes hierarchical structure pattern of society. 


\section{REFERENCES}

Allen, Robert L, 2017, Oral Tradition: A Study in Historical Methodology, New York: Routledge.

Allport, GW, 1958, The Nature of Prejudice, Garden City, New York: Doubleday.

Anderson, B, 1983, 2006; Imagined Community: Reflection on the Origin and Spread of Nationalism, Revised edition, London :Verso.

1991, "GagasanTentangKe-kuasaanDalamKebudayaanJawa", dalam M Budiardjo (ed), Aneka PemikiranTentangKuasadanWibawa, Jakarta: PustakaSinarHarapan, pp. 44-125.

Bandura, A, 1977.Social Learning Theory, New Jersey, Englewood-Cliffs: Prentice-Hall, Inc.

Bauman, Z, 1995, "Searching for a Centre that Holds", in M Featherstone, S Lash, and R Robertson (ed). Global Modernities, London: SAGE Publications, pp 140-154.

Bourdieu, P, 1994, "Structure, Habitus, Power: Basis for a Theory Symbolic", in NB Dirks et al (ed), Culture/Power/ History: A Reader Contemporary In Social Theory, Princeton, New Jersey: Princeton University Press, pp. 155-198.

Coon, D, 1985, Essentials of Psychology: Exploration and Application. $3^{\text {rd }}$ edition, New York: West Publishing Company.

Edberg, Mark, 2015, Essentials of Health Behavior: Social and Behavioral Theory in Public Health: Jones and Bartlett Learning.

Elias, N, 1988. "KerangkaUntukSebuahTeoriPeradaban", dalam HD Evers (ed). TeoriMasyarakat: Proses PeradabanDalamSistemDunia Modern,Terjemahan, Jakarta: Obor, hal 3-24.

Ellis, A, 1982, "Rational Emotive Therapy", in G Corey (ed), Theory and Practice of Counseling and Psychotherapy, Mon-terey, California: Brooks/Cole Publishing Company, pp. 170-183.

Evers, HD, 1988. "Proses Peradaban: RagamPolaDuniaAtauSistemDunia", dalam (ed), TeoriMasyarakat: Proses PeradabanDalamSistemDunia Modern, Terjemahan, Jakarta: Obor, hal 25-31.

Geertz, C, 1960. The Religion of Java, The Free Press of Glencoe.

---------, 1993, The Interpretation of Cultures, Hammersmith, London: Fontana Press.

1996, "Religion as Cultural System", in DL Pals (ed), Seven Theories of Religion, New York: OUP, pp. 233-265.

Goddard, Cliff and Zhengdao Ye, 2016, "Happiness" and "Pain" Across Languages and Cultures, Amsterdam: John Benjamins Publishing Company.

Gordon, S, 2003. The History and Phylosophy of Social Science, Taylor and Francis e-library.

Goulding, R and M Goulding, 1978, "Injunctions, Decisions, and Redeci-sion”, Transactional Analysis Journal, $6(1): 41-48$

Kartodirdjo, S, 1984. "Respons-responsPadaPenjajahanBelanda di Jawa: MitosdanKenyataan", Prisma, 11 (XIII): 3-11.

Keesing, RM, 1981, "Theories of Culture", in RW Casson (ed), Language, Culture and Cognition: Anthropological Perspectives, NY: Macmillan, pp. 42-63.

Kleden I, 1986. "MembangunTradisiTanpaSikapTradisional: Dilema Indonesia AntaraKebudayaandanKebangsaan", Prisma, 8 (XV): 69-86.

Lichbach MI, 1994, "What Makes Rational Peasants Revolutionarity?: Dilemma, Paradox and Irony in Peasant Collective Action", World Politics, 46 (3): 383-418.

Lombard D, 2005, Nusa Jawa: SilangBudaya, Jakarta: GramediaPustakaUtama.

Luke, TW, 1995. "New World Order or Neo-world Order: Power, Politics and Ideology in InformationalizingGlocalization", in M Featherstone, et al (ed). Global Modernities, London: SAGE Publications, pp 91-107.

Luke, TW, 2003, "Real Interdependence: Discursivity and Concursivity in International Politics", in Francois Debrix (ed), Language, Agency, and Politics in a Constructed World, Armonk, New York: M.E. Sharpe.

Mahadi, Tengku Tengku Sepora and Sepideh Moghaddas Jafari, 2012, "Language and Culture", International Journal of Humanities and Social Science, Vol. 2 No. 17: 230-235.

Markus HR, and S Kitayama, 1994, "The Cultural Construction of Self and Emotion: Implication for Social Behavior”, In S Kitayama, HR Markus (eds), Emotion and Culture: Empirical Studies of Mutual Influence, Washington DC: APA, pp. 89-130.

Miles MB, and AM Hubermann, 1994, "Data Management and Analysis Methods", in NK Denzindan YS Lincoln (ed), Handbook of Qualitative Research, London: Sage Publi-cations, pp.428-443.

Newcomb, TM, 1960, "Varieties of Interpersonal Attraction", in D Cartwright and A Zander (ed), Group Dynamics: Research and Theory, $2^{\text {nd }}$ edition, New York: Harper \& Row, Publishers, pp. 104-118.

Onghokham, 1984, "ReaksiTerhadapKekalahan", Prisma, (11): 45-48.

Oyserman D, and MJ Packer, 1996, "Social Cognition and Self-concept: A Socially Contextualized Model of Identity", In JL Nye and AM Brower (ed), What's Social About Social Cognition?, London: SAGE, pp. 175204. 
Parrott, W Garrod, 2001, Emotions In Social Psychology: Essential Readings, Philadelphia: Taylor and Francis.

Rahman B, 1995, "NilaiKulturaldanDifferensiasiAgraria di PedesaanJawa", Disertasi, Yogjakarta: UGM.

Reed, Mark S. et al; Dec. 2010, “What Is Social Learning?”, Ecology and Society, Vol. 15, No. 4: pp. 1-10.

Ridjal, Tadjoer, 2004, Tamparisasi Tradisi Santri Pedesaan Jawa, Surabaya: Kampusina

Thompson M, Ellis R, Wildavsky A, 1990. Cultural Theory, Boulder, San Francis-co: Westview Press.

Van Meiji, Toon; 2008, "Culture and Identity in Anthropology: Reflections on 'Unity' and 'Uncertainity' in The Dialogical Self”, International Journal for Dialogical Science, Vol. 3, No. 1: 165-190.

Vansina J, 1973, Oral Tradition: A Study in Historical Methodology, Harmondsworth, Middlessex: Penguin Books.

Wallace AFC, 1981, "Culture and Cognition", in RW Casson (ed), Language, Culture and Cognition: Anthropological Perspectives, NY: Macmillan, pp. 65-73.

Waters, M, 1994. Modern Sociological Theory, London: SAGE.

Williams R, 1977. Marxism and Literature, Oxford, NY: Oxford University.

Wouters C, 1992, "On Status Competition and Emotion Management: The Study of Emotions as a New Field", in M Featherstone (ed), Cultural Theory and Cultural Change, London: SAGE: 299-251.

\section{GLOSSARY}

Santrinization $=$ is a local term in the Java language that describes the process of socialization of the religious traditions of the nuances of Islam.

Wong njero = identity symbol of family members of village cleric's family

Wong njaba = a symbol to depict the identity of communities members that politically and socially are located in lower strata

Wong mambu-mambu= family members who are descendants of ancestors who in the early days santrinization marriages between "wong njero" and "wong njaba".

Magersaren=people whose homes live with other people's yard

Ngemblek= take teak wood at forest

Santri=According Geerts, students are representing the attitude focuses on aspects of the Islamic syncretism, generally correlating to the merchant (and with certain elements among the farmers); Someone who displays the symbols of Islam in daily life; or a Islamic boarding school pupil

Priyayi=According to Geertz, "gentry" are those whose attitude focuses on aspects of Hinduism and is associated with elements of the bureaucracy.

Abangan=Geertz defines "abangan" which represent the position of emphasizing aspects of Javanese syncretism thorough, and is widely associated with the elements of farmers among the population.

Pembabat alas $=$ village founder

Kiai $=$ islamic leader

Slametan $=$ islamic communal ceremony

Subasita $=$ call or greeting honor

Kedhung=the deepest recesses of the riverbed

Kedhusan $=$ people who have many sin, or act like goat

Wedhus = goat

Ramban $=$ goats behavior to eat grass or leaves in any place

Mbanggel $=$ refuse the order

Mreman purakan $=$ work together with daily wage

Wong loran $=$ people who live in north village area

Wong kidulan = people those who reside in southern village

Tahlilan = ritual homage to the spirits of the deceased, in the form of prayers and reading of sentences option, in Arabic

Nyepaki= providing food and smoke incense

Nyulayani adat $=$ deviation from tradition

Padhatampare $=$ a local term that means fellow citizens Nahdliyin

Wong kidulan $=$ members of village founder

Wong loran = immigrants

Genderaijo = green flag, it means a symbol santris

Genderoabang=red flag, the symbol means "abangan"

Kiratabasa=According Ridjal (2004) "kiratabasa"stands for "roughly but real", it means that the meaning of a word that is on the meaning of the syllables, and the syllable is an abbreviation of a word

Mandala $=$ the environment, or the territory of a religious institution

Gakjawa or durungjawa = a term that describes the development of attitudes in childhood; or immature

Radajawa $=$ a term that describes the development of attitudes in adolescence; or early adulthood 
Wisjawa $=$ a term that describes the development of the attitude of those who are older or mature Durungsantri $=$ do not manifest the symbol identity of santri,

Radasantri $=$ manifest symbol of identity of rather santri,

Wis santri=have manifested a identity symbol of santri.

Ngramekna masjid= efforts for the prosperity of the mosque, meaning that invites citizens to treat mosques not only perform the function of ritual, but also a social function

Sak-takirtakirdhing $=$ A term that means evenly divided in equal parts, or each got the same section 